\title{
O INSTANTE DA AGONIA E AS REINVENÇÕES ATLÂNTICAS DAS PRÁTICAS FÚNEBRES NA DIÁSPORA: VILAS DE CAMPANHA, BAEPENDI E SÃO JOÃO DEL-REI (1780-1830)
}

Leonara Lacerda Delfino Márcio Eurélio Rios de Carvalho ${ }^{1}$

RESUMO: Este artigo se propõe a entender os significados construídos pelos confrades do Rosário em contexto de exílio, junto a seus descendentes, em torno dos signos, cultos, celebrações e práticas vinculados à releitura das práticas do bem morrer católico no Novo Mundo. Em vista disso, nos preocupamos em averiguar como as experiências e acepções de morte foram recriadas na outra margem do Atlântico a partir da apropriação da liturgia católica em interação com as heranças africanas de ancestralidade. Para tanto, foram utilizados testamentos post-mortem de libertos, a documentação confrarial das irmandades do Rosário, os relatos de missionários católicos em África e as imagens de litografia da ars moriendi.

Palavras-chave: rituais de passagem, bem-morrer, diáspora atlântica, irmandade do Rosário.

ABSTRACT: This article aims to understand the meanings constructed by the confreres of the Rosary in exile context, along with their descendants around the signs, worship, celebrations and practices linked to the reinterpretation of well die Catholic practices in the New World. In view of this, we care to find out how the experiences and meanings of death were re-created on the other side of the Atlantic from the Catholic liturgy appropriation in interaction with African heritage ancestry. Therefore, we used testaments postmortem freed, the brotherhood documentation of the brotherhoods of the Rosary and the reports of Catholic missionaries in Africa and lithography images from ars moriendi..

Keywords: rites of passage, well-die, Atlantic diaspora, the Rosary brotherhood.

Introdução: os rituais de passagem nas duas margens do Atlântico:

O campo de estudos sobre a história social da morte no Brasil foi inaugurado com João José Reis (1991: 89) em sua obra - A morte é uma festa — ao adotar metodologias e propostas analíticas empregadas pela Escola dos Annales, como o uso do conceito das mentalités, enquanto recurso analítico para o entendimento dos comportamentos coletivos da sociedade escravista perante as transformações fúnebres do Oitocentos. Nesta proposta, o autor adverte - a partir de Van Gennep (2011) — para a existência de ritos de passagem ou

\footnotetext{
${ }^{1}$ Sobre os autores: Leonara Lacerda Delfino é Doutora em História pela UFJF. Pós-doutoranda em História pelo PPGH/UNIMONTES. E-mail: leonaralacerda@yahoo.com.br. https://orcid.org/0000-0001-5422-4980. Márcio Eurélio Rios de Carvalho é Doutor em História pela UFMG. Professor da Universidade do Estado de Minas Gerais (UEMG/Campanha). E-mail: eureliomarcio@ gmail.com. https://orcid.org/0000-0003-1630-6023.
} 
de separação e os cerimoniais para a incorporação no além. Segundo o autor, a separação e a incorporação tinham por objetivo integrar a alma do falecido, de forma segura, na vida póstúmulo, tendo para isso o respaldo ritualístico de despedida dos vivos.

De qualquer modo, a realização adequada dos rituais funerários visava atender a segurança dos vivos e dos mortos. Temia-se a vingança dos últimos, caso seus pares terrenos não lhes garantissem uma transição segura ou deixassem de cumprir as prescrições de suas "últimas vontades". No sentido inverso, isto é, quando as exéquias obedeciam ao rigor prescrito pelas orientações do moribundo; a alma alcançaria o descanso espiritual, podendo, posteriormente, interceder pelos vivos, inclusive os auxiliando, no momento da hora derradeira, a realizar o trespasse solidário para a comunidade dos mortos. Sendo assim, tanto a religião cristã quanto o sistema religioso centro-africano primavam pelos cuidados de separação e de integração dos mortos.

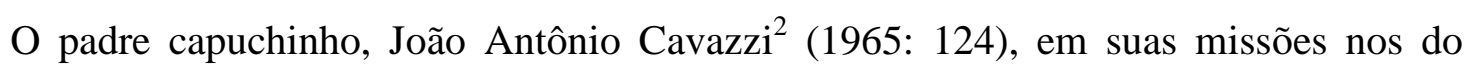
Congo, Angola e Matamba - entre os anos de 1640 a 1670 - nos lembra de uma figura especializada no Reino do Congo em "amassar a água e a terra" para untar o corpo do cadáver, concorrendo, assim, para o descanso espiritual do morto. Fábio Leite (2008: 102116) - ao tratar sobre a questão ancestral na Costa do Marfim — adverte sobre a importância dos rituais de passagem (cerimoniais funerários) na própria elaboração social do ancestral nas culturas iorubás. Para o autor, o destino final do morto se efetuava em duas modalidades: a reencarnação ou a transformação do espírito em entidade ancestral — através do encaminhamento ao Ebolo (espaço sagrado da ancestralidade).

Deste modo, a vida pós-túmulo era revelada aos sacerdotes especializados por meio de sonhos, transes secretos, jogos de adivinhação, etc.. Após descoberta a causa da morte e o "destino" da alma, dava-se início aos rituais de preparação do cadáver, sepultamento, sacrifícios, cânticos e danças mortuárias, refeições comunitárias e orações específicas. A morte para estes povos era vista como um processo de desagregação das forças vitais e de transfiguração da existência do plano físico visível para o mundo espiritual invisível. Por seu turno, a vivência das celebrações mortuárias significava a própria transição ritual do estatuto de morto para o de ancestral, em reafirmação do estreitamento dos laços comunitários e de reiteração do mundo dos vivos com o reino dos ancestrais (Ebolo).

\footnotetext{
${ }^{2}$ A primeira edição da obra, em italiano, foi publicada em 1687. No entanto, trabalhamos com a versão em português publicada em 1965 .
} 
Ainda em solo africano, os rituais de passagem e as práticas mortuárias foram marcadas pelo processo de hibridização cultural $^{3}$, onde a confluência de ritos, símbolos e signos católicos do bem morrer recebiam apropriações de acordo com o sistema de revelações ${ }^{4}$ dos povos bantos, assentado numa estrutura religiosa de plasticidade e de orientação de códigos compatível à permutabilidade de símbolos e de linguagens religiosas de diferentes matrizes culturais (Thornton, 2004: 331). Foi assim que a Virgem Maria passou a ser venerada como nkisi (signo sagrado), Jesus Cristo e outras figuras, como Santo Antônio de Pádua, cultuados em sociedades secretas de kimpasi $^{5}$ e difundidas pelos nlekes ${ }^{6}$ e mestres intérpretes, com caráter bastante autônomo, em relação à rigidez ortodoxa. Outrossim, muitos missionários franciscanos, jesuítas e capuchinhos, mesmo apelando para políticas de violência de incêndio à Casa dos Ídolos, tiveram que se adequar aos códigos culturais locais para que a catequização, enquanto política imperialista, se mantivesse nessas regiões centro-africanos (Sapede, 2012).

Deste modo, os povos ovimbundos expandiram seu campo simbólico de tratamento funerário, ao adotarem a missa fúnebre, o sepultamento católico e as recitações de rosários e ladainhas cristãs, sem dispensarem os ritos tradicionais que levavam dias de cerimoniais, agregando oferendas, sacrifícios, danças fúnebres, banquetes e tambores (Thornton, 2008: 95). A redefinição semântica desses rituais de passagem está vinculada à reorientação identitária cultural desses grupos que, ao praticarem uma nova religiosidade - o catolicismo centro-africano - delinearam pontos de intercessão substanciais no espaço de mobilidade e de circulação de símbolos e práticas da diáspora atlântica. Um exemplo mais tácito desta

\footnotetext{
${ }^{3}$ Para Canclini (1998: 18-19): “a hibridização não é sinônimo de fusão sem contradições, mas sim que pode ajudar a dar conta de formas particulares de conflito geradas na interculturalidade (...). [Deste modo] entendo por hibridização processos socioculturais nos quais estruturas ou práticas discretas, que existam de forma separada, se combinam para gerar novas estruturas, objetos e práticas. Cabe esclarecer que as estruturas chamadas discretas foram resultado das hibridizações, razão pela qual não podem ser consideradas fontes puras".

${ }^{4}$ Segundo Thornton (2004: 312-354), a incorporação dos preceitos católicos se efetuava, conforme a convergência das crenças cristãs aos ideais de ventura e desventura, princípios ordenadores do universo cosmológico daquelas populações afro-centrais.

${ }^{5}$ De acordo com Slenes (2006: 288), os kimpasi floresceram principalmente durante as crises coletivas; eram movimentos secretos comunitários que visavam propiciar os bisimbi (ancestrais) e remediar os problemas temporais daquela sociedade. O culto reunia "a devoção de pedras e objetos sagrados da terra nkisi", uma língua secreta e iniciações em clareiras das matas, com do transe espiritual, isto é, da incorporação do espírito-guia, "cujo nome e identidade carregava [o praticante] durante o resto da vida." O principal culto de aflição ou kimpasi conhecido pela historiografia africanista foi elaborado por Beatriz Kimpa Vita, sacerdotisa congolesa que se dizia a encarnação de Santo Antônio de Pádua e pregava a crença da origem centro-africana de Cristo e da Virgem Maria. Kimpa Vita foi queimada, como herege, em 1706.

${ }^{6}$ Segundo Thiago Clemêncio Sapede (2012: 183), "nleke é um termo recorrente na documentação quando trata dos chamados 'escravos da igreja', este vocabulário é, em kikongo, um adjetivo com o sentido de juventude (que deu origem a palavra moleque no português brasileiro. Isto demonstra que estes "escravos" eram em geral jovens congoleses vinculados à igreja e o trabalho sacramental, portanto aprendizes. Mas não eram exclusivamente jovens; parece existir uma hierarquia entre eles na qual escravos mais velhos ocupavam local de maior prestígio."
} 
hibridização cultural em reinos centrais - Congo, Angola e Benguela — pode ser notado pela proliferação dos entambes, celebrações funerárias caracterizadas pela fluidez dos símbolos e ritos e pelo redimensionamento das práticas tradicionais, em razão da apropriação das crenças católicas do bem morrer (Delfino, 2015: 399).

Segundo Selma Pantoja (2004: 117), o cerimonial do sepultamento perdurava dias e contava também com a celebração de missas, recitação do rosário e ladainhas à Nossa Senhora, além das danças, sacrifícios, possessões e oferendas costumeiras. Antônio Cavazzi (1965: 128), preocupado em conter as práticas tidas como pagãs, descreve o cerimonial como um festejo de oito dias, em que os participantes dançavam, sem descanso, "rodavam como peões", falavam vozerias "confusas" e davam o "de comer" ao defunto, lançando comidas e bebidas em sua sepultura. Nestes cerimoniais, era bastante comum a participação dos xinguilas (sacerdotes). A função destes adivinhos consistia em "descobrir" a causa de morte do falecido e conduzir os rituais necessários para o apaziguamento do espírito em situação de passagem (Sweet, 2007: 210).

Em terras brasílicas, um relatório eclesiástico apontou como os sepultamentos mais afastados dos parâmetros ortodoxos nomeados por tambes geravam tumulto em razão do uso intensivo dos atabaques, oferendas e bebidas (Sweet, 2007: 211). Outro indício semelhante foi registrado por Dom Antônio de Guadalupe, autoridade eclesiástica das Minas que reclamava à Coroa, quanto ao aspecto gentílico e pagão dos cerimoniais fúnebres, em razão da ocorrência de vozerias, atabaques noturnos, ajuntamento com comidas e bebidas lançadas às sepulturas (AEAM, Governos Episcopais, 1726).

Estes testemunhos, demostram como os gestos propiciatórios da boa morte e os rituais de passamento se fizeram também de maneira híbrida e plural na Colônia. (REIS, 1991). Uma das práticas recorrentes em preparar o defunto para os "rituais de passagem" consistia em, após a lavagem do corpo, a infusão aromática de ervas para evitar o cheiro da decomposição. Além disso, havia o cuidado em cortar o cabelo, aparar as unhas e revestir o cadáver com a mortalha de escolha do falecido ou de seus familiares (determinada em testamento, quando havia algo para testar). Ademais, antes da morte propriamente dita, os vizinhos, confrades, parentes e familiares próximos se reuniam para a despedida definitiva, prestando solidariedade de orações e socorros materiais à família do moribundo (Reis, 1991).

A morte ideal, ou seja, a "boa morte" era aquela previamente preparada e assistida de forma coletiva, segundo os preceitos do bem morrer católico ${ }^{7}$. As pessoas inseridas numa

\footnotetext{
${ }^{7}$ A doutrina do bem morrer diz respeito a uma série de gestos propiciatórios e crenças que levava o individuo a se preparar para o passamento seguro em direção à salvação eterna. Não se restringia aos atos imediatos ante-
} 
piedade barroca tinham um verdadeiro pavor da morte solitária ou da morte súbita, sem a solidariedade dos amigos e familiares e o pior, sem a recepção dos sinais divinos (sacramentos). A assistência aos moribundos constituía num dos principais deveres cristãos, e por isso foi normatizada em alguns estatutos de irmandades, como o Rosário de Baependi ${ }^{8}$ (localizada no Sul de Minas), quando os confrades prescreveram em uma das cláusulas a obrigação dos irmãos em assistir aos enfermos: "Se alguns dos irmãos cair (sic) em pobreza ou se cair em alguma enfermidade, aleijão ou cegueira, a irmandade o sustentará, curará e investirá, e por sua morte lhe fará os benefícios comprometidos." (ACMC, Compromisso do Rosário dos Pretos, Vila de Baependi, 1819).

Em Campanha, identificamos em seu Museu Regional, algumas litografias que se reportam às imagens idealizadas do bem morrer experenciadas pelos confrades do Rosário no Oitocentos. ${ }^{9}$ Nessas estampas, os temas da morte do homem justo e a morte do homem pecador foram reproduzidos de modo a acentuar a importância do julgamento individual e as consequências de uma vida devota ou pecadora. Conforme sugerem as representações imagéticas abaixo:

mortem, como a redação do testamento e a busca pelos sacramentos, mas incluía, sobretudo, o comportamento de penitência e de investimento nos bens de salvação ao longo da vida. A consolidação desta doutrina se efetivou com a expansão da crença no Purgatório e nas possibilidades de mudar o "destino" da alma, em relação à condenação e à salvação eterna, mediante a "religião das boas obras", utilizada como instrumentalização das práticas compensatórias e de aquisição do perdão divino. Grosso modo, a ars moriendi e a doutrina do macabro se difundiram, principalmente, na Baixa Idade Média, quando as representações iconográficas das igrejas reportavam-se à "pedagogia do medo", às ameaças escatológicas do Apocalipse e às possibilidades de redenção pela passagem no "inferno provisório" (VOVELLE, 2010: 130).

${ }^{8}$ A Irmandade do Rosário dos Homens Pretos de Baependi recebeu seu alvará de funcionamento emitido pela Mesa de Consciência e Ordens em 1821. Em seu compromisso, encaminhado àquela instância em 1819, propunha que fossem eleitos, além do corpo administrativo, um rei e uma rainha em caso de ausência da realeza vitalícia. No início, a confraria instalou-se em um dos altares laterais no interior da Matriz de Santa Maria de Montserrat. No entanto, com o advento das esmolas, em grande parte recolhidas pelos folguedos realizados pelos moçambiques, tendo à frente seu capitão, logo esses irmãos deram início a construção de sua capela particular. Segundo um memorialista da cidade, o empenho para a construção do templo envolveu toda a comunidade negra local, que pôde contar também com os esforços de José Cabra, conhecido como "Pai José", escravo de José Carlos Nogueira, que assumiu o cargo de procurador durante a construção do templo. Para maiores informações, cf.: PELÚCIO, 1942.

9 A Vila de Campanha da Princesa, fundada em 1799, era considerada o celeira da região do extremo-sul de Minas, em razão da sua economia ter prosperado na dedicação do cultivo de gêneros alimentícios (arroz, feijão, milho) e na criação de porcos e gado vacum. A Irmandade do Rosário nesta Vila surgiu alocado no altar lateral da Matriz de Santo Antônio no início do Oitocentos e seu templo foi edificado em 1822. Cf.: DELFINO, 2015: 143. 


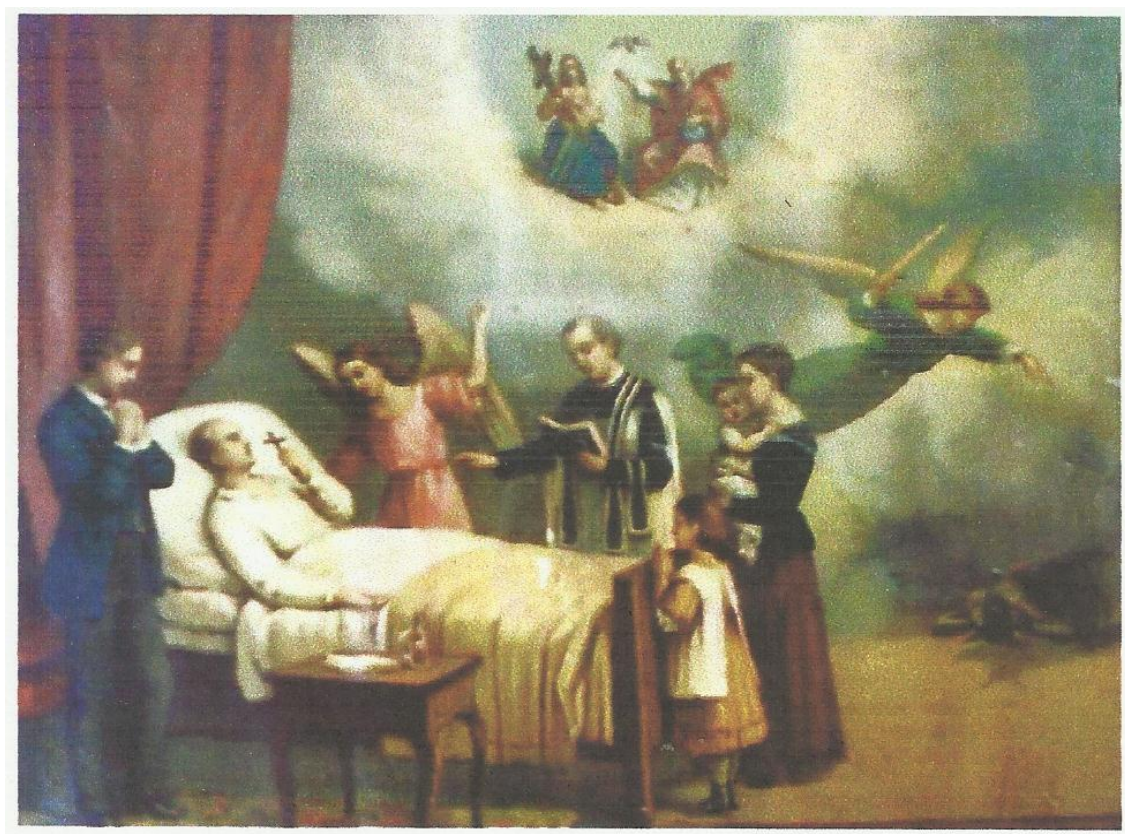

IMAGEM 1: “A morte do Homem Justo (s/d)". MRSM, Campanha- MG, Acervo de Arte Sacra.

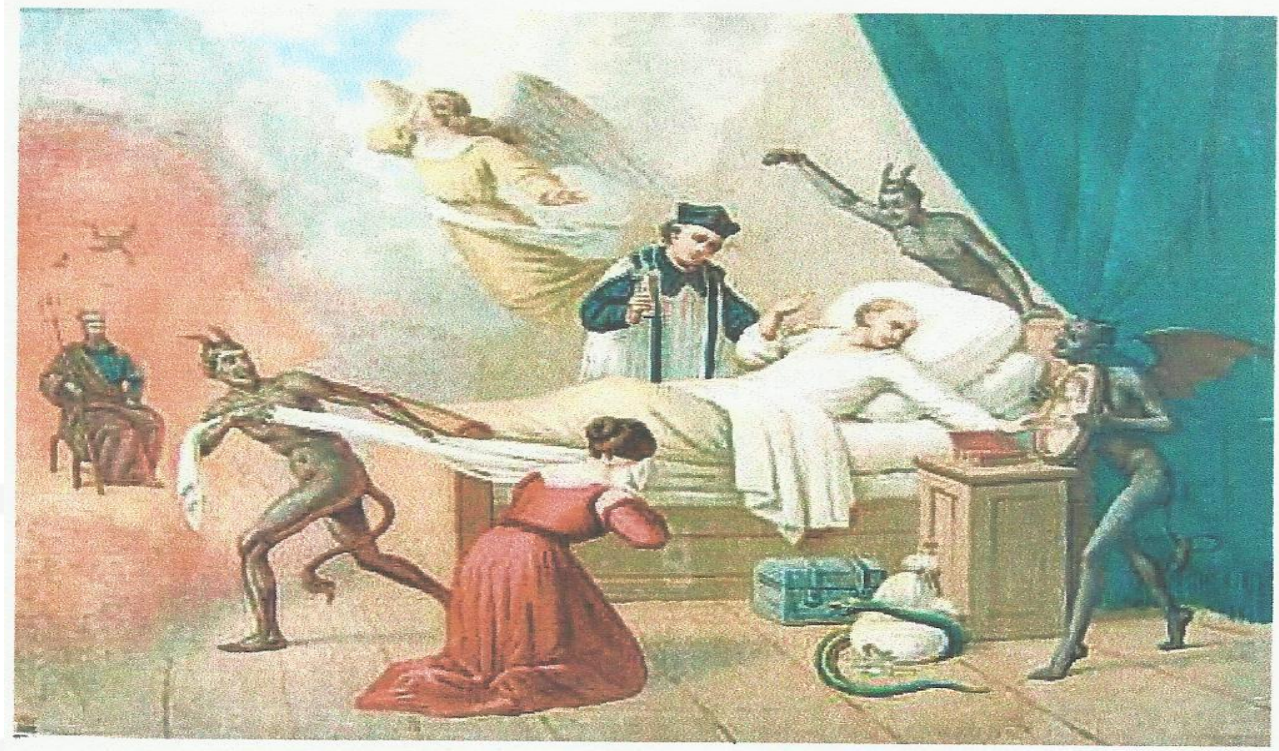

IMAGEM 2: “A morte do Homem Ímpio (s/d)". MRSM, Campanha- MG, Acervo de Arte Sacra

Pela primeira imagem podemos notar a cena do juízo individual perpassada no quarto do moribundo, como prescreviam as representações doutrinárias da ars moriendi católica. $\mathrm{O}$ homem agonizante, deitado em sua cama, se via acompanhado de sua família e assistido por um sacerdote, o qual conduzia a leitura da bíblia. Rodeado por seres celestiais em sinal de atuação pela salvação da alma para expulsar o maligno, o homem justo segurava em suas mãos, os símbolos da fé (o crucifixo e o rosário da Virgem Maria). Ao fundo do quarto, transcorria a cena do juízo: à frente do enfermo — com seu semblante sereno — nota-se a figura de um anjo de luz acenando para a Santíssima Trindade; à direita da imagem há uma 
figura maligna, quase imperceptível; deitado ao chão, em meio às sombras. A cena sintetiza, através do duelo cósmico, o triunfo das forças celestes e a necessidade, para um católico, deste cerimonial "apaziguante que solenizava a passagem necessária - o passamento" atuando como canal de salvação espiritual (Ariès, 2012, p 55). Nesse sentido, a representação da morte do homem justo se encarrega em transmitir ao fiel a capacidade do devoto em levar, até o leito de morte, a demonstração de atitudes pias.

Em oposição à primeira litografia, a morte do homem ímpio praticamente emite uma mensagem avessa à da primeira imagem. Em seu leito de morte, seres infernais povoam o ambiente do quarto, provocando desordem, puxando lençóis, em comemoração a vitória ao se apoderarem da alma do homem pecador. O anjo, único ser celestial da cena, se afasta progressivamente do moribundo, tapando os olhos para o portal em chamas em representação do inferno. Sentado e coroado como um rei, a figura maligna — portando um tridente nas mãos, como se fosse o cetro real - aguarda a chegada da alma para a danação eterna. Deitado com o rosto virado para o lado oposto do sacerdote, o homem ímpio parecia recusar os últimos sacramentos, se sentindo mais atraído pela imagem refletida no espelho, objeto pelo qual trazia um dos demônios.

À frente do leito de morte se encontra uma figura feminina (provavelmente esposa), debruçada em lágrimas em sinal de falta de preparo para o enfrentamento do momento derradeiro. O comportamento inverso pode ser notado pela família do homem justo, em função dos seus gestos de serenidade na hora da despedida, Ao lado do enfermo surge um rapaz jovem com mãos postas demonstrando estar em momento de contemplação e oração. Já em relação à morte do pecador, a agonia é retratada como desespero e apego nítido aos bens terrenos. Pela mobília do quarto, é possível observar a presença de um baú de madeira, um saco de moedas envolvido por uma serpente e um porta-joias ao lado da cabeceira da cama do enfermo em sinal do ambiente materialista e do apego aos prazeres e confortos terrenos. (ver imagens 1 e 2)

Em vista destas representações imagéticas, podemos constatar a valorização do julgamento individual presente nas estampas, junto à ideia de que a agonia era percebida como um momento tragicamente decisivo pelos fiéis, isto é, o momento decisivo a ser traçado a batalha espiritual ante-mortem. Neste instante poderia ser definida a salvação eterna ou a danação da alma. Se não houvesse arrependimento no ato da confissão e da contrição final, certamente a alma agonizante não teria chances de purgar seus pecados no além intermediário, aniquilando, assim, todas as suas possibilidades de redenção. 
Este sentimento de temor do instante derradeiro fez com que muitos testadores forros, ingressos na Irmandade do Rosário de São João del-Rei ${ }^{10}$, relatassem seus receios de se verem desamparados pelas forças celestes ou de sucumbirem às tentações colocadas como prova no momento em que a alma também se via fragilizada. A apreensão atinente ao juízo individual se fez presente, por exemplo, no depoimento testamentário de José da Silva Lima procedente da Costa da Mina (AMNSP-SJDR, Testamento de José da Silva Lima, 22/08/1787, Livro de Óbitos, 1790, mar-1792-nov.).

O irmão do Rosário demonstrou anseio na hora da agonia, ao suplicar pela intercessão do seu "anjo da guarda" e de "todos os santos e santas da Corte do Céu" naquele "último instante". Implorou também o forro à Virgem Maria para que o servisse como "advogada" perante o "Tribunal Divino" (AMNSP-SJDR, Testamento de José da Silva Lima, 22/08/1787, Livro de Óbitos, 1790, mar-1792-nov.). Do mesmo modo, Francisco Gonçalves dos Santos, preto liberto de Nação Angola, temeu a sua hora e suplicou como "verdadeiro católico," querer morrer dentro dos preceitos cristãos (AMNSP-SJDR, Testamento de Francisco Gonçalves dos Santos,11/07/1797, Livro de Óbitos, 1799, abr.- 1800, mai.). Luiz Gonçalves da Trindade Crioulo, morador da "Fazenda do Lenheiro" decidiu abrir o seu testamento "por temer a morte" e por "ser mortal", desejando com aquela redação testamentária pôr sua "alma a caminho da salvação" (AMNSP-SJDR, Testamento de Luiz Gonçalves da Trindade Crioulo, 24/02/1807, Livro de Óbitos, 1804, mar-1807, mai.). Outro irmão — José Ferreira de Sá Preto de Nação Mina, rogou à Virgem Maria — referenciada como "minha Mãe," para que intercedesse por ele, junto com seu "anjo de guarda e santo do seu nome," diante do momento em que fosse apresentado a seu "Salvador." (AMNSP-SJDR, Testamento de José Ferreira de Sá Preto de Nação Mina, 11/04/1797, Livro de Óbitos, 1796, jan.- 1799, abr.).

Estando em seu "perfeito juízo e entendimento", a liberta da Costa da Mina, Josefa da Costa Gouvêa, também filiada ao Rosário, resolveu dar início a seu testamento por não "saber quando Deus" iria chamá-la para que ela fosse servi-lo na "bem-aventurança" (AMNSPSJDR, Testamento de Josefa da Costa Gouvêa de Nação Mina, 12/02/1797; Livro de Óbitos, 1800, mai.- 1804, mar.). A moradora do Ingá e devota do Rosário, Vitória Gonçalves Ferreira, pediu que na última hora, a Virgem Maria, sua "especial intercessora”, não a desamparasse no momento que sua alma se desligasse do corpo e partisse deste mundo (AMNSP-SJDR,

\footnotetext{
${ }^{10}$ A Irmandade do Rosário em São João del-Rei é considerada a agremiação mais antiga de pretos devotos da capitania das Minas. Fundada em 1708, a confraria teve seu primeiro templo edificado ao lado esquerdo do Córrego Lenheiro em 1719. Cf.: DELFINO, 2017: 50.
} 
Testamento de Vitória Gonçalves Ferreira, 28/09/1782,; Livro de Óbitos, 1782, ago-1786, jun).

Ao temer pelo dia incerto, a irmã do Rosário, Tereza Franca Preta Forra encomendou sua alma à Mãe de Deus, às “Almas do Purgatório" e pediu pelo "Santíssimo Sacramento", em nome do "preciosíssimo sangue de Cristo e de sua misericórdia infinita," para que intercedessem junto a ela naquele instante de agonia (AMNSP-SJDR, Testamento de Tereza Franca Preta Forra, 11/05/1795; Livro de Óbitos, 1792, nov-1796, jan.). Da mesma forma, Tereza da Silva Mina - "por não saber o momento em que Deus a levaria deste mundo" resolveu dar entrada aquele testamento para deixar registradas as suas últimas vontades. Encomendou a irmã que sua alma fosse entregue à Santíssima Trindade por tê-la criado, e rogou ao "Pai Eterno" pela "paixão do seu filho", pedindo, em especial, a proteção de Nossa Senhora do Carmo (AMNSP-SJDR, Testamento de Tereza da Silva Mina, 18/12/1788, Livro de Óbitos, 1796, jan- 1799, abr.). Rita Bastos Preta Forra, preocupada em colocar a sua "alma a caminho da salvação", invocou todos os santos da corte celestial, seu anjo da guarda e, em especial, o chefe das milícias celestes, São Miguel Arcanjo, para que pesasse suas virtudes na balança da justiça divina (AMNSP-SJDR, Testamento de Rita Bastos, 09/11/1783, Livro de Óbitos, 1786, jun.-1790, mar.).

Depois de tantas invocações celestes, pedidos de intercessão e encomendação pela alma em interface às apreensões da hora incerta, o testador confrade dava início à exposição de suas "últimas vontades", isto é, a disposição dos seus bens entre os herdeiros e a distribuição dos legados pios. Cláudia Rodrigues (2005: 40), ao trabalhar o sentimento de temor produzido pelo discurso dos testamentos de libertos, chama atenção para a própria estrutura do documento cuja prioridade textual residia na exposição da protestação de fé e na nomeação dos intercessores. A ordem de interesses expressava nesta linguagem discursiva uma mentalidade social voltada para o aparelhamento do bem morrer e da salvação.

Sendo assim, para evitar que a morte chegasse de surpresa, as pessoas agonizantes, "mas de pé” ou em "perfeito juízo" e raramente "em bom estado de saúde e perfeito juízo", escolhiam cuidadosamente as disposições de suas exéquias. Deste modo, deveriam ficar muito bem claras as orientações sobre o lugar de sepultamento, as formas de encomendação da alma, as missas em sufrágio, a indumentária fúnebre e as esmolas aos afetos terrenos e transcendentes, pois não raro as pessoas deixavam esmolas, joias e outros legados aos santos de devoção.

Em consulta aos 71 testamentos de irmãos e irmãs libertos da confraria do Rosário de São João del-Rei, certificamos que a escolha da mortalha constituiu uma exigência de $77.46 \%$ 
dos testadores. ${ }^{11}$ O hábito do "Patriarca São Francisco" foi a indumentária mais requisitada, com $21.12 \%$ (ver tabela). A crença presente no imaginário cristão acerca do poder milagroso do cordão de S. Francisco, como instrumento de resgate das almas sentenciadas, pode ter atraído a procura deste vestuário entre os libertos.

\begin{tabular}{|l|l|l|}
\hline Mortalha & $\mathbf{N}^{\mathbf{0}}$ & $\mathbf{\%}$ \\
\hline Hábito de São Francisco & 15 & 21.12 \\
\hline Mortalha sob eleição do testamenteiro (a) & 13 & 18.30 \\
\hline Lençol/ lençol branco & 13 & 18.30 \\
\hline Hábito de Nossa Senhora do Carmo & 11 & 15.49 \\
\hline Hábito de Nossa Senhora da Conceição & 1 & 1.40 \\
\hline Hábito de São Francisco de Paula & 1 & 1.40 \\
\hline Hábito de linho branco & 1 & 1.40 \\
\hline Hábito preto ou azul & 1 & 1.40 \\
\hline Hábito de seriguilha & 1 & 1.40 \\
\hline "Hábito decente" & 1 & 1.40 \\
\hline "Hábito que puder" & 1 & 1.40 \\
\hline Hábito de Santa Tereza & 1 & 1.40 \\
\hline Mortalha preta & 1 & 1.40 \\
\hline Não Menciona & 7 & 9.85 \\
\hline Rasgado/ apagado & 3 & 4.22 \\
\hline Total & 71 & 100.00 \\
\hline
\end{tabular}

Tabela 1: Mortalha, segundo os testadores forros do Rosário (1781-1828). Fonte: AMNSP-SJDR, Testamentos extraídos dos Livros de Óbitos (1781-1828).

Em segundo lugar, a escolha da indumentária ficou a encargo do testamenteiro. Identificamos igualmente este mesmo percentual em relação ao uso do lençol (branco ou sem distinção de cor) nas preferências apontadas pelas referências testamentárias (18.30\%). ${ }^{12}$ João José Reis (1991: 126) aventa a hipótese desta indumentária se relacionar ao Santo Sudário ou ainda ao fato de apresentar-se mais acessível entre os segmentos mais pobres da sociedade. Em Salvador, o lençol branco envolto nos cadáveres foi muito recorrente, fazendo desta cor o símbolo mortuário de muitas nações africanas. Posteriormente, a indumentária branca se tornou um dos distintivos dos rituais fúnebres do candomblé (Reis, 1991: 124).

Rodrigues (1997: 205), ao identificar uma preferência acentuada dos africanos pela mortalha branca no Rio de Janeiro, acrescenta outros significados à cor mortuária, que se

\footnotetext{
${ }^{11}$ Em nossa amostra dos 71 testadores, 50 eram mulheres e 21 homens. No que se refere à distribuição étnica, havia: 7angolas, 4 benguelas, 1 cambinda, 3 congos, 9 crioulos, 2 “da Costa”, 41 minas (1 courana e 1 nagô), 3 pardos e 1 preto. Cf.: AMNSP-SJDR, Testamentos extraídos dos Livros de Óbitos (1781-1828).

${ }^{12}$ Em Salvador, a mortalha branca foi preferência de 73,5\% dos africanos indicados pelos assentos de óbitos (1835-1836); enquanto que o hábito preto foi usado por $12.2 \%$ e o hábito franciscano pelo mesmo percentual dos pretos sepultados. Já os crioulos indicaram o hábito branco em 54,5\%, o preto em 18,2\% e o franciscano, em 3.0\%. Cf.: Reis, 1991: 126. Para o Rio de Janeiro, Rodrigues (1997: 202) destacou entre os segmentos dos forros, o uso da mortalha de Santo Antônio (22\%), a indumentária branca (21\%), o hábito de N. S. da Conceição $(15 \%)$ e as vestes pretas (14.3\%). Entre os escravos: a mortalha branca (32.7\%), a preta (19.7\%) e o hábito de N. S. da Conceição (16.8\%). Este levantamento foi feito a partir dos registros de óbito da Freguesia do Santíssimo Sacramento do Rio de Janeiro, entre os intervalos amostrais de 1812 a 1885.
} 
ligaria à ancestralidade entre os povos bantos. A prática do branqueamento com a pemba "uma espécie de giz branco" — nos rituais de iniciação e o uso de água de argila branca para o tratamento das enfermidades demonstram como a cor invocava "a imagem viva dos espíritos dos antepassados; por isso, para alguns grupos étnicos bantos, o branco representava a cor dos defuntos (...)."

Em terceiro lugar identificamos, na escolha dos libertos, o Hábito de N. S. do Monte do Carmo/ Carmelo ou de N. S. do Carmo. Mary Karasch (2000: 370) foi precursora em aventar a popularidade do bentinho entre os negros, por enxergarem no objeto mágico a possibilidade de afugentar "as forças invisíveis." A adesão maciça à crença do purgatório pelos segmentos de cor pode ter levado muitos desses irmãos do Rosário a buscar nesta indumentária, o auxílio para o alcance do privilégio sabatino, ou seja, o anseio de ser libertado no sétimo dia após a morte, através do uso do bentinho. Nesse sentido, a escolha da mortalha, via invocação dos santos, expressava uma forma de identificação entre a alma e os seres intercessores, permitindo ao falecido o passaporte e a proteção para integração satisfatória na vida pós-túmulo (Rodrigues, 1997: 196).

Deste modo, compreendemos o instante da agonia e a ideia do duelo final, ocorrido no leito de morte, como um dos pontos mais valorizados pelos depoimentos testamentários dos irmãos forros, muitos deles de origem africana. Tal fato reporta-se aos significados de apropriação da doutrina do purgatório e dos rituais de passagem cristãos, em que a hora derradeira poderia definir a salvação ou a condenação do indivíduo, conforme as crenças católicas. Por seu turno, consideramos que a adesão maciça às práticas do bem morrer pelos grupos exilados só foi possível, em razão da importância do significado da morte e das práticas fúnebres ocupada nas matrizes culturais das sociedades centro-africanas na prétravessia consoante o depoimento dos missionários católicos em África. Por outro lado, devemos ressaltar que a experiência de contato e de hibridização dos símbolos culturais em culturas antecedentes à diáspora, forneceu bases para a reinvenção da existência e para a reconstrução de identidades sociais coletivas em situação de homogeneização e de imposições de forças sobre corpos e pensamentos daqueles indivíduos exilados. Todavia, as significações de vida e de morte foram reconfiguradas em razão da centralidade das práticas mortuárias na estruturação das cosmologias bantu e dos sistemas de valores das sociedades centro-africanas. No item a seguir, procuramos tecer balizas acerca da expansão do culto dos mortos e da sufragação das almas protagonizadas por uma segmentação etnorreligiosa ocorrida dentro da confraria do Rosário dos Pretos de São João del-Rei. 


\section{A doutrina do Purgatório, o culto das almas milagrosas e a Nobre Nação de Benguela}

A crença no "além intermediário" ou do purgatório ${ }^{13}$ foi bastante difundida entre os diversos segmentos da diáspora, sobretudo pelo apelo à intercessão dos mortos na definição do destino dos vivos (culto às almas milagrosas), algo bastante dialogável com o poder de intervenção da ancestralidade na mobilização do complexo ventura/desventura apresentado em linhas anteriores. Com efeito, os relatos do viajante Thomaz Ewbank (1976) são elucidativos para demonstrar alguns aspectos da hibridização atlântica quanto às vivências do imaginário social da morte no Novo Mundo. Um caso ilustrativo pode ser notado pela difusão de altares, caixa de esmolas e murais das populares alminhas ${ }^{14}$ na sociedade escravista. Segundo o viajante inglês, "homens e mulheres" — de todas as nações do "Congo, Angola, Cambinda e Costa do Ouro e de regiões mais remotas da Etiópia" — se viam sensibilizados ante as almas figuradas em uma caixa de esmolas sita à Rua do Conde do Rio de Janeiro Oitocentista. Considerada um "sermão escrito em caracteres eternos," a representação das almas transmitia um cenário de dor em que duas crianças (uma branca e outra negra) pareciam implorar por esmolas e orações ante ao sofrimento purgativo instaurado pelo estado das penas provisórias (Ewbank, 1976: 215-216).

De acordo com o estrangeiro, dificilmente as pessoas transeuntes poderiam se recusar a "esmola aos inocentes que assim imploraram alguns vinténs ou uma pataca com gritos, lágrimas e mãos erguidas" (Ewbank, 1976: 215). Nesse sentido, a retratação de dois rebentos expostos aos tormentos do fogo purgativo - com mãos levantadas, aos gritos e lágrimas tinha por objetivo despertar o lado afetivo dos caminhantes para a concessão de esmolas e orações às almas inocentes sentenciadas. A criança negra ao lado da branca sugere a

\footnotetext{
${ }^{13}$ De acordo com Le Goff (1995), a crença no Purgatório é muito antiga dentro cristianismo, no entanto, a definição de uma localização precisa e de uma doutrina sistematizada a despeito do período de purificação dos mortos foi desenvolvida no século XIII. Segundo o autor, até o final do século XII a palavra purgatorium não existia como substantivo, mas a ideia de expiação post-mortem era presente desde o postulado de São Paulo de que o "fogo porá à prova a obra de cada um" (Coríntios, 3,13 ). Vários intelectuais do catolicismo contribuíram para sistematização do juízo particular e da problematização da dualidade estrutural do imaginário cristão (céu/ inferno), entre eles podemos citar: Santo Agostinho (Confissões); o Papa Gregório, o Grande (Moralia in Job, Dialogi); São Bernardo (Purgatorium), São Boaventura (Quatro Livros de Máximas de Pedro Lombardo), São Tomás de Aquino (Suplemento), Santa Catarina de Viena (Tratado sobre o Purgatório). As principais elaborações dogmáticas sobre o além intermediário foram feitas por ocasião dos Concílios de Lyon (1274), de Florença (1438-1445) e de Trento (1545-1563).

${ }^{14} \mathrm{O}$ culto às "alminhas" foi intenso em Portugal. Geralmente, estas imagens eram pintadas em monumentos públicos (paredes, azulejos, etc.), podendo ter feições infantilizadas, com a mensagem inscrita embaixo: "lembrai-vos de nós" (Gonçalves, 1959: 28). Para Campos (2013: 67), as Cruzes das Almas na Capitania de Minas tiveram uma projeção maior em relação às "alminhas propriamente." No entanto, as representações das almas nas "caixinhas votivas", "com figuras pintadas ao alto, brancas e negras, com olhos de brasa e boca de fogo, levantando os braços no meio de labaredas vermelhas, listradas de amarelo" estavam por todas as partes, representadas em portas de igrejas, boticas e tabernas (Moraes Filho, s/d: 221).
} 
preocupação dos devotos das almas em fortalecer a doutrina do purgatório também entre aos segmentos de escravizados e remanescentes do cativeiro, como demonstra a imagem a seguir:

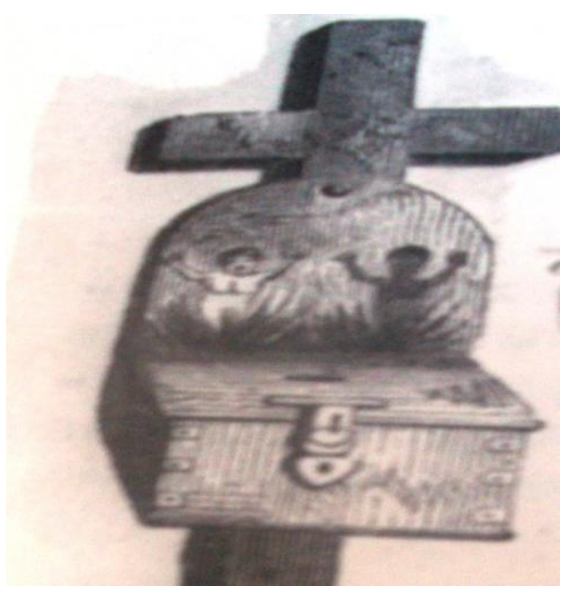

IMAGEM 3: Caixa de esmolas das almas, Rio de Janeiro. (Ewbank, 1976: 216)

Em estudo recente, Delfino (2017) procurou demonstrar como o Purgatório se estabeleceu como crença efetiva presente no imaginário social da morte de muitos segmentos da sociedade escravista, ocupando, principalmente, um lugar privilegiado entre os escravizados e libertos provenientes da diáspora atlântica associados à confraria do Rosário de São João del-Rei. ${ }^{15}$ Nesta Irmandade, a devoção das almas, em estágio de purgação, foi bem aceita entre os estrangeiros no exílio e de seus descendentes em razão da valorização dada à assistência aos mortos, através das missas votivas, e da capacidade destes em atuar a favor dos vivos, conforme a crença no poder milagroso das almas sentenciadas.

O culto às almas atingiu maior organização e coesão dos seus praticantes, quando um grupo de confrades do Rosário fundou, no interior da irmandade, uma congregação denominada por Nobre Nação de Benguela ${ }^{16}$, com o objetivo de potencializar a assistência aos irmãos defuntos, através da expansão dos sufrágios dos seus "parentes de nação". Ao aderir à Irmandade do Rosário dos Pretos de São João del-Rei, cada confrade teria, segundo o

\footnotetext{
${ }^{15}$ Ver também o trabalho desenvolvido por Brügger e Oliveira (2009).

${ }^{16}$ A existência deste reinado foi identificada através da localização do Livro de Certidões de Missas, esmolas e doações da "Nobre Nação", aberto em 1803 cujo documento se encontra alocado no Arquivo da Paróquia de Nossa Senhora do Pilar de São João del-Rei (AMNSP-SJDR). Neste manuscrito foram registrados os assentos dos sufrágios dos irmãos falecidos, o nome do celebrante, o número de missas intencionadas à cada defunto e o valor de esmola recebido para a celebração. Seu surgimento remonta pelo menos desde a última década do século XVIII, quando João Ladino mandou celebrar, em 1793, missas intencionadas às almas de Ana e Mariana Lopes, sob a regência do Padre Luiz Pereira Gonzaga. Nota-se, ainda, neste a presença de reis, duques, marqueses, conselheiros, tesoureiros e procuradores, enquanto membros diretivos da organização voltada para a assistência aos irmãos vassalos defuntos, isto é, na distribuição de missas votivas e na realização do féretro, além das concessões de esmolas habituais à Virgem do Rosário. Cf.: AMNSP- SJDR, Livro de Certidão de Missas da Nobre Nação Benguela (1803).
} 
estatuto, o benefício de dez missas fúnebres. ${ }^{17}$ Para reforçar a liturgia da morte - em investimento aos veículos tradicionais do bem morrer (missas votivas às almas do purgatório e sepultamento ad sanctos) — os benguelas, ganguelas, angolas e alguns de seus descendentes se reuniram em um espaço próprio - Palácio da Nobre Nação de Benguela. Neste palácio — adquirido a custa e finta dos irmãos ${ }^{18}$ —os confrades congregados certamente tiveram maior autonomia para recriar suas heranças e memórias, com uma linguagem própria e mais aproximada dos símbolos de ancestralidade. ${ }^{19}$

As reuniões públicas aconteciam por ocasião dos folguedos da praia $^{20}$, festejos com tambores que tinham por objetivo venerar Nossa Senhora do Rosário e arrecadar esmolas para beneficiar as almas dos parentes de nação, através dos sufrágios. Os tambores, em favor das almas, ocorriam nas proximidades do Córrego Lenheiro, onde havia um Altar das Almas, voltado para a adoração e realização das práticas mágicas às almas do purgatório.

Os irmãos benguelas redimensionaram seus rituais fúnebres, assentados na ancestralidade, ao reverenciar — pela liturgia católica do bem morrer — seus parentes de nação falecidos. A proximidade dos tambores da Nobre Nação com às águas do Córrego

\footnotetext{
${ }^{17}$ AMNSP- SJDR, Cap. 9, Compromisso da Irmandade de Nossa Senhora dos Pretos de São João del-Rei, 1787, Cap. 8 e Cap. 10, Estatutos da Irmandade de Nossa Senhora do Rosário dos Pretos de São João del-Rei, 1841.

18 O imóvel foi comparado, a custa e finta dos irmãos benguelas, em nome de dois pretos forros. A casa não poderia ser vendida, trocada ou usada para fins pessoais desses compradores, em virtude do recinto servir abrigo da realeza negra, como sugere o trecho: "João Machado Alves Fontes e João Thomaz Ferreira Guimarães Pretos Forros que servimos nesta Nobre Nação de Benguela [ilegível]. Certifico e por termos fé em como estas casas é da Nobre Nação de Benguela, declarando que os ditos compradores João Machado Alves Fontes e João Thomaz Ferreira Guimarães compraram estas casas com o dinheiro das esmolas que tiramos entre forros e cativos e do que está estabelecida por Palácio Real de toda Nação Benguela e por seus ditos compradores serem forros é que estão por cabeça desta compra, não porque fazem donos e possuidores como seus, porque foi a custa e finta entre todos que consistem cativos desta Nobre Nação e não poderão dispor nem vender as ditas casas sem a Nação toda junta fazerem Mesa e haver bem e para a clareza de todos que achamos presente mandemos lavrar o presente termo em que se assinaram os da dita Nação que se acham presente dado e passado em o Real Palácio. Aos 30 de novembro de 1803 anos. Eu Euzébio José Assis (?) Pereira da Silva, escrivão que escrevi e assinei com os ditos, como em frente: João Henrique da Costa, o Duque da Nação (...).AMNSP-SJDR, Livro de Certidões de Missas da Nobre Nação Benguela, 1803.

${ }^{19}$ Consoante Slenes (1999: 243): "o culto aos ancestrais na África tem um significado amplo, político, social e religioso, especialmente no caso da homenagem feita aos "ancestrais fundadores" que, como os africanos dizem "deram origem a nossa vida e nos trouxeram às terras onde vivemos." Mais especificamente, podemos ter certeza de que entre os ovimbundu e no reino de Loango, como de fato acontecia na terra dos bakongo, a ratificação de um novo chefe político envolvia um ritual que o aproximava dos ancestrais originários do grupo e que simbolicamente recriava o próprio ato de fundação deste."

${ }^{20} \mathrm{Em}$ várias passagens do livro há referências sobre os "folguedos da praia": "Recebi da Nação Benguela dos folguedos da Praia e para a ajuda das obras de N. Sra. Do Rosário em 26 de abril de 1807, seis oitavas e seis vinténs de ouro. O Tesoureiro Manoel José de Oliveira." Cf.: Arquivo da Matriz de Nossa Senhora do Pilar de São João del-Rei, AMNSP- SJDR, Livro de Certidão de Missas da Nobre Nação Benguela (1803). A Praia ou Prainha era uma referência antiga dada à localidade onde se situava o Córrego Lenheiro ou do Tejuco, cujas margens separavam a Vila em duas partes, antes da construção da primeira ponte de madeira em 1719. Segundo Guimarães (1996: 39-65), no mesmo local, foi feito "em pedra a ponte do Rosário". Já o Oratório das Almas, foi construído nas proximidades do Córrego Lenheiro, por volta de 1750 e "não se tem notícia sobre a data do seu desaparecimento".
} 
Lenheiro reporta-se efetivamente, à simbologia da kalunga ${ }^{21}$ ligada ao culto dos mortos nas culturas centro-africanas. As águas representadas pela metáfora do espelho reflexivo entre os dois mundos, remetiam também à morada do reino dos mortos e o veículo de comunicação e invocação dos ancestrais pelo cadenciamento dos tambores. Deve ser este um dos motivos que explique a simbologia do Rosário $^{22}$ vinculado à narrativa mítica do resgate de sua imagem em águas sagradas.

\section{Considerações Finais:}

Ao longo da análise, tivemos a preocupação em demonstrar a experiência devocional atlântica como espaço de apropriação e de negociação de símbolos entre as heranças centroafricanas e os códigos católicos presentes na doutrina do bem morrer, através dos processos de hibridização cultural vinculados à religiosidade de contato desenvolvida desde o período da pré-travessia. Nesse sentido, os ritos funerários se estabeleceram como espaço privilegiado dessas interações simbólicas, em razão da centralidade da cultura mortuária na estruturação dos sistemas de valores das sociedades centro-africanas.

Com efeito, entendemos que a apropriação desses símbolos não deve ser pensada a partir do aspecto de exterioridade, na medida em que os devotos ressignificaram os sentidos catequéticos a partir de suas interpretações situacionais e aspectos valorativos vivenciados na diáspora, sem se desvincularem das heranças e memórias oriundas da pré-travessia . Deste modo, constatamos que o culto das almas, promovida pelos irmãos do Rosário em localidades como Campanha, Baependi e São João del-Rei, propiciou o redimensionamento da noção de ancestralidade e da experiência e a significação da morte no Novo Mundo.

\section{Referências documentais:}

\section{ACMC, Arquivo da Cúria Metropolitana de Campanha- MG}

Compromisso da Irmandade de Nossa Senhora do Rosário dos Pretos da Vila de Baependi (1819);

Compromisso da irmandade de Nossa Senhora do Rosário dos Homens Pretos da Leal Vila de Campanha (1814).

\footnotetext{
${ }^{21}$ Ver os trabalhos de Slenes (1999: 246) e (2008: 193-218).

${ }^{22}$ Ver o relato sobre o aparecimento da imagem do Rosário nas águas, identificado por Borges (2005: 191) em análise do Estatuto da Irmandade de N. Sra. Do Rosário do Serro (1729).
} 


\section{AEAM, Arquivo Eclesiástico da Arquidiocese de Mariana:}

Governos Episcopais, 1726.

\section{AMNSP- SJDR, Arquivo da Matriz de Nossa Senhora do Pilar de São João del-Rei-MG:}

Compromisso da Irmandade de Nossa Senhora do Rosário dos Pretos da Vila de São João Del Rei (1787);

Compromisso da Irmandade de Nossa Senhora do Rosário dos Pretos da Cidade de São João del-Rei (1841);

Livro de Certidões de Missas da Nobre Nação Benguela -1803.

Livros de Óbitos (1781-1828).

Testamento de José da Silva Lima, 22/08/1787, Livro de Óbitos, 1790, mar-1792-nov.).

Testamento de José da Silva Lima (22/08/1787). Anexo ao assento de óbito (26/07/1790); Livro de Óbitos (1790, mar-1792, nov.).

Testamento de Francisco Gonçalves dos Santos (11/07/1797). Anexo ao assento de óbito (12/12/1799); Livro de Óbitos (1799, abr.- 1800, mai.).

Testamento de Luiz Gonçalves da Trindade Crioulo (24/02/1807). Anexo ao assento de óbito (25/04/1807); Livro de Óbitos (1804, mar-1807, mai).

Testamento de José Ferreira de Sá Preto de Nação Mina (11/04/1797). Anexo ao assento de óbito (07/07/1797); Livro de Óbitos (1796, jan- 1799, abr).

Testamento de Josefa da Costa Gouvêa de Nação Mina (12/02/1797). Anexo ao assento de óbito (25/02/1802); Livro de Óbitos (1800, mai- 1804, mar).

Testamento de Vitória Gonçalves Ferreira (28/09/1782). Anexo ao assento de óbito (26/10/1782); Livro de Óbitos (1782, ago-1786, jun).

Testamento de Tereza Franca Preta Forra (11/05/1795). Anexo ao assento de óbito (13/06/1795); Livro de Óbitos (1792, nov-1796, jan).

Testamento de Tereza da Silva Mina (18/12/1788). Anexo ao assento de óbito (03/04/1799); Livro de Óbitos (1796, jan- 1799, abr.).

Testamento de Rita Bastos (09/11/1783). Anexo ao assento de óbito (01/05/1788); Livro de Óbitos (1786, jun-1790, mar.).

\section{MRSM, Museu Regional do Sul de Minas (Campanha):}

Estampa, A Morte do Homem Justo, (s/d). Acervo de Arte Sacra; Estampa, A Morte do Homem Ímpio, (s/d). Acervo de Arte Sacra. 


\section{Fontes impressas:}

CAVAZZI, João Antônio. Descrição histórica dos três Reinos do Congo, Matamba e Angola. $1^{a}$ Ed.: 1687. Vol. 1 e 2. Lisboa: Junta de Investigações do Ultramar, 1965.

EWBANK, Thomas. A vida no Brasil ou Diário de uma visita à terra do cacaueiro e da Palmeira. Belo Horizonte: Livraria Editora Ltda.I Editora da USP, 1976.

FILHO, Mello Moraes. Festas e Tradições populares do Brasil. Rio de Janeiro: S/ Ed, s/d. GUIMARÃES, Geraldo. São João Del Rei, século XVIII. História Sumária. São João Del Rei. S/Ed, 1996.

GONÇALVES, Flávio. Os painéis do Purgatório e as “alminhas" populares. Matosinhos: Papelaria e Tipografia Leixões, 1959.

PELÚCIO, José Alberto. Templos e Crentes. Baependi. s/ Ed. 1942

RAMOS, Arthur. O negro brasileiro. Etnografia religiosa e psicanálise. Rio de Janeiro: Civilização Brasileira, 1934.

\section{Referências bibliográficas:}

ARIÈS, Philipe. História da Morte no Ocidente. Da Idade Média aos nossos dias. Rio de Janeiro: Nova Fronteira, 2012.

BORGES, Célia Maia. Escravos e Libertos nas Irmandades do Rosário: devoção e solidariedade em Minas Gerais: séculos XVIII e XIX. Juiz de Fora: editora da UFJF, 2005.

BRÜGGER, S. M. \& OLIVEIRA, A, J. M. de. "Os Benguelas de São João Del Rei: tráficoatlântico, religiosidade e identidades étnicas. (Séculos XVIII e XIX).” In: Revista Tempo, v. 13, n 26, Niterói-RJ, 2009, pp. 177-204.

CAMPOS, A. As irmandades de São Miguel e as Almas do Purgatório: Culto e iconografia no Setecentos Mineiro. Belo Horizonte: Editora C/Arte, 2013

CANCLINI, Nestor. Culturas Híbridas: estratégias para pensar e sair da modernidade. São Paulo: Edusp, 1998.

DELFINO, Leonara L. O Rosário dos Irmãos Escravos e Libertos: Fronteiras, Identidades e Representações do Viver e Morrer na Diáspora Atlântica. Freguesia do Pilar-São João DelRei (1782-1850). Tese de Doutorado em História. Juiz de Fora-MG: PPGHIS, 2015.

2017.

O Rosário das Almas Ancestrais. Belo Horizonte: Clio Gestão Cultural Editora,

GENNEP, Arnold Van. Os ritos de passagem. Petrópolis: Vozes, $2^{\text {a }}$ Ed., 2011.

HEYWOOD, (Org.), Diáspora negra no Brasil. São Paulo: Contexto, 2008.

KARASCH, Mary C. A vida dos escravos no Rio de Janeiro 1808-1850. São Paulo, Companhia das Letras, 2000.

LE GOFF, Jacques. O Nascimento do Purgatório. $2^{a}$ edição. Lisboa: Editorial Estampa, 1995. LEITE, Fábio Rubens da Rocha. A Questão Ancestral: África negra. São Paulo: Palas Athena: Casa das Áfricas, 2008.

PANTOJA, Selma. "Inquisição, degredo e mestiçagem em Angola." In.: Revista Lusófona de Ciência das religiões. Ano III, 2004, n 5/6, p. 117-136.

REIS, J. J. A Morte é uma Festa: ritos fúnebres e revolta popular no Brasil do século XIX. São Paulo: Companhia das Letras, 1991.

RODRIGUES, Cláudia. Lugares dos mortos na cidade dos vivos. Tradições e transformações fúnebres no Rio de Janeiro: Secretaria Municipal da Cultura, 1997. 
- Nas fronteiras do Além. A secularização da morte no Rio de Janeiro, séculos XVIII e XIX, Rio de Janeiro: Arquivo Nacional, 2005.

SAPEDE, Thiago Clemêncio. Muana Congo, Muana Nzambi Ampungu: poder e catolicismo no reino do Congo pós-restauração (1769-1795). Dissertação de Mestrado em História. São Paulo: FFLCH/ USP, 2012.

SLENES, Robert, Na senzala uma flor. Esperanças e recordações na formação da família escrava. Brasil, Sudeste, século XIX. Rio de Janeiro: Nova Fronteira, 1999.

"A árvore de Nsanda transplantada: cultos kongo de aflição e identidade escrava no sudeste brasileiro (século XIX)". In: LIBBY, D. \& FURTADO, J. F. (Orgs.) Trabalho escravo, trabalho livre. Brasil e Europa, séculos XVIII e XIX. São Paulo: Annablume, 2006, 273-316.

. "A Grande Greve do Crânio do Tucuxi: Espíritos das águas centro-africanas e identidade escrava no início do século XIX no Rio de Janeiro." In.: HEYWOOD, (Org.), Diáspora negra no Brasil. São Paulo: Contexto, 2008, p. 193- 218.

SWEET, James, Recriar África: Cultura, parentesco e religião no mundo afro-português (1441-1770), Lisboa, Edições 70, 2007.

THORNTON, John. A África e os africanos na formação do mundo Atlântico (1400-1800). Rio de Janeiro: Elsevier, 2004.

. "Religião e vida cerimonial no Congo e áreas Umbundu, de 1500 a 1700". In.: HEYWOOD, (Org.), Diáspora negra no Brasil. São Paulo: Contexto, 2008, pp. 81-100.

VOVELLE, As Almas do Purgatório ou Trabalho de Luto. Tradução Aline Meyer e Roberto Cattani. São Paulo: Editora UNESP, 2010. 